ISSN : 2303-1514 | E-ISSN : 2598-5949

\title{
THE INFLUENCE OF REWARDS AND PUNISHMENTS ON THE STUDENTS' LEARNING MOTIVATION AT GRADE V
}

\author{
Septi Ayu Lestari ${ }^{1}$, Rahmat Aziz $^{2}$, Samsul Susilawati ${ }^{3}$ \\ ${ }^{1,2,3}$ Universitas Islam Negeri Maulana Malik Ibrahim Malang, Malang, Indonesia \\ 109septiayu@gmail.com, ${ }^{2}$ azira@uin-malang.ac.id, ${ }^{3}$ susilawati@pips.uin-malang.ac.id
}

\section{PENGARUH PEMBERIAN REWARD DAN PUNISHMENT TERHADAP MOTIVASI BELAJAR SISWA KELAS V}

\begin{tabular}{|c|c|}
\hline ARTICLE HISTORY & ABSTRACT \\
\hline $\begin{array}{l}\text { Submitted: } \\
\text { 02 Juni } 2021 \\
02^{\text {th }} \text { June } 2021\end{array}$ & $\begin{array}{l}\text { Abstract: Students' low motivation can be caused by how teachers teach in the learning } \\
\text { activities. Teachers can use rewards and punishments to trigger students' learning motivation } \\
\text { in the classroom. The data were collected through a questionnaire with a Likert scale. } \\
\text { Meanwhile, the samples were selected by total sampling. Then, the data were analyzed by using } \\
\text { multiple regression analysis to determine the effect of giving rewards and punishments on } \\
\text { students' learning motivation either partially or simultaneously. The results showed that } \\
\text { the tcount was } 0.203 \text { and ttable was } 0.306 \text {; thus, Ho was accepted and Ha was rejected. As a } \\
\text { result, giving rewards had no significant positive effect on students' learning motivation at } \\
\text { grade V of SDN Dadaprejo } 01 \text {, Kecamatan Junrejo, Kota Batu. Hence, partially giving } \\
\text { rewards had no significant positive effect on motivation. In addition, this study also obtained } \\
\text { that the tcount was } 4.552 \text { and the ttable was O.306. Thus, Ho was rejected and Ha was } \\
\text { accepted. This result indicated that punishment had a significant positive effect on the students' } \\
\text { learning motivation at grade Vof SDN Dadaprejo 01, Kecamatan Junrejo, Kota Batu. Hence, } \\
\text { partially, punishment had a significant positive effect on learning motivation. }\end{array}$ \\
\hline
\end{tabular}

Keywords: rewards, punishment, learning motivation

Accepted:

09 September 2021

$09^{\text {th }}$ September 2021

Published:

27 Oktober 2021

$27^{\text {th }}$ October 2021

\begin{abstract}
Abstrak: Kurang optimalnya motivasi siswa di kelas bisa disebabkan oleh bagaimana cara guru mengajar di dalam kegiatan belajar mengajarnya. Dalam proses kegiatan belajar mengajar di kelas, guru bisa menggunakan pemberian reward dan punishment untuk memicu motivasi belajar siswa. Metode pengambilan data yang dalam penelitian ini adalah kuesioner (angket) dengan instrument skala likert. Sedangkan teknik pengambilan sampel menggunakan total sampling dengan cara diambil dari seluruh jumlah populasi. Anlaisis data yang digunakan adalah analisis regresi berganda untuk mengetahui pengaruh pemberian reward dan punishment terhadap motivasi belajar siswa baik secara parsial maupun secara simultan. Hasil penelitian menunjukkan bahwa: (1) Diperoleh hasil $t_{\text {hitung }}(0.203) \leq t_{\text {tabel }}(0.306)$. Artinya, Ho diterima dan Ha ditolak. Hal ini menunjukkan bahwa "Tidak adanya pengaruh yang positif signifikan pemberian reward terhadap motivasi belajar siswa kelas V SDN Dadaprejo 01 kecamatan junrejo kota batu". Berarti dapat disimpulkan bahwa secara parsial tidak adanya pengaruh positif signifikan terdapat pada reward terhadap motivasi. (2) Diperoleh hasil thitung (4.552) $\geq t_{\text {tabel }}$ (0.306). Artinya, bahwa Ho ditolak dan Ha diterima. Hal ini menunjukkan bahwa "Adanya pengaruh positif signifikan pemberian punishment terhadap motivasi belajar siswa kelas V SDN Dadaprejo 01 Kecamatan Junrejo Kota Batu”. Berarti dapat disimpulkan bahwa secara parsial ada pengaruh positif signifikan punishment terhadap motivasi.
\end{abstract}

Kata Kunci: pemberian reward, punishment, motivasi belajar

\section{CITATION}

Lestari, S. A., Aziz, R., \& Susilawati, S. (2021). The Influence of Rewards and Punishments on the Students' Learning Motivation at Grade V. Primary: Jurnal Pendidikan Guru Sekolah Dasar, 10 (5), 1152-1165. DOI: http://dx.doi.org/10.33578/jpfkip.v10i5.8418

\section{PENDAHULUAN}

Dalam dunia pendidikan juga dibutuhkan pengetahuan tentang motivasi karena dunia pendidikan menghadapi peserta didik yang unik yang dapat dilihat dari segi prilaku, kepribadian, perhatian, motivasi, dan 
berbagai aspek psikologi lainnya yang berbeda antara individu satu dengan individu lainnya. Pada diri peserta didik terdapat kekuatan psikologi yang menjadi penggerak untuk belajar yang dimana belajar itu merupakan suatu proses perubahan prilaku yang dapat diamati, diukur, dan dinilai secara konkrit. Semua itu dilakukan dengan maksud mencari atau menambah ilmu pengetahuan, menambah atau meningkatkan keterampilan, dan membentuk watak, sikap, atau kepribadian(Wahyudin, 2011). Motivasi merupakan kekuatan yang menggerakkan seseorang untuk mencapai cita-cita yang diinginkannya. Motivasi disini berasal dari dalam diri siswa yang tumbuh karena adanya semangat untuk meraih prestasi yang tinggi, hal itu juga disebabkan oleh kesadaran yang timbul dari diri siswa. Sedangkan untuk motivasi belajar yang berasal dari luar diri siswa biasanya muncul karena adanya rangsangan-rangsangan belajar yang berasal dari luar sehingga siswa terpacu untuk menanggapi rangsangan tersebut dengan cara menjadi lebih rajin dan lebih giat lagi untuk belajar. Tidak ada siswa yang belajar tanpa adanya motivasi.

Sayangnya hingga saat ini masih ditemui banyak permasalahan tentang kurang optimalnya motivasi belajar pada siswa sehingga pembelajaran di dalam maupun di luar kelas tidak berjalan secara efektif dan menyebabkan semakin menurunnya prestasi belajar siswa. Selain itu, siswa yang mampu membangkitkan motivasi belajar yang berasal dari dalam masih tergolong jarang. Hal ini dikarenakan kesadaran yang dimiliki oleh siswa untuk berprestasi lebih tinggi masih terbatas. Dengan demikian, motivasi belajar yang berasal dari luar perlu mendapatkan perhatian dan tindakan dari guru di kelas.

Guru sangat berperan penting dalam mengendalikan jalannya proses kegiatan belajar mengajar di kelas dan diharapkan bisa mengemban tugasnya dengan sebaik-baiknya serta dapat memperbaiki moral peserta didiknya. Namun, dalam mengemban tugasnya tersebut guru selalu diharapkan dengan permasalahan yang sama, yakni masalah pengelolaan kelas serta minat peserta didik yang rendah dalam kegiatan belajar di kelas. Rendahnya motivasi siswa di kelas bisa disebabkan oleh metode mengajar yang digunakan oleh guru dalam kegiatan belajarnya. Guru hanya menjelaskan materi sepanjang jam pelajaran, sedangkan siswa hanya duduk manis mendengarkan, sehingga itulah sebabnya membuat siswa bosan dan jenuh selama jam pelajaran berlangsung. Sehingga sebagai seorang guru tidaklah hanya mampu menyampaikan materi pelajaran dengan baik, tetapi ia harus mampu memotivasi siswanya. Sebab motivasi disini merupakan salah satu faktor yang menentukan berhasil atau tidaknya siswa dalam proses belajar mengajar. Salah satu upaya yang dapat dilakukan guru untuk meningkatkan motivasi siswa dalam belajar yaitu dengan memberikan reward dan punishment.

Pemberian reward disini dapat berupa pujian, pujian adalah alat motivasi yang positif. Setiap orang senang dengan pujian, termasuk anak-anak senang dipuji atas suatu pekerjaan yang telah selesai dikerjakannya dengan baik. Sedangkan punishment atau punishment adalah reinforcement negatif. Punishment yang mendidik dibutuhkan dalam dunia pendidikan, kesalahan peserta didik karena melanggar disiplin dapat diberi punishment berupa sanksi(Zahroh, 2015). Guru bisa menggunakan reward (hadiah) dan punishment (punishment) sebagai penguat eksrinsik untuk mendorongnya mencapai prestasi dan menjaga motivasi beajar peserta didik dalam belajarnya. Keduanya dilatarbelakangi oleh konsep teori behavioristik dimana menurut teori behavioristik belajar adalah perubahan tingkah laku sebagai akibat dari adanya interaksi antara stimulus dan respon(Ginanjar., 2013).

Kebutuhan-kebutuhan yang dimiliki oleh siswa antara lain kebutuhan organisasional (fisik), kebutuhan sosial (afiliasi), kebutuhan intelektual (berprestasi), 
dan kebutuhan keindahan, yang semuanya mengarah pada aktualisasi diri. Melalui kebutuhan-kebutuhan tersebut, guru dapat menggerakkan motivasi siswa melalui pemenuhan kebutuhan-kebutuhan tersebut namun masih dalam koridor pendidikan (Achmad Rifa'i, 2011). Sehingga guru harus memahami respon yang cocok agar bisa menstimuluskan siswanya. Selain faktor kebutuhan pokok tersebut latar belakang keluarga siswa juga mempengaruhi kuat tidaknya respon yang diberikan oleh siswa. Oleh karena itu pengetahuan dan pemahaman tentang latar belakang serta syarat-syarat dalam pemberian reward harus benar-benar diperhatikan. Sehingga dampak negative dari pemberian reward dapat dihindari. Salah satu kebutuhan yang dimiliki siswa adalah kebutuhan penghargaan yang terdapat dalam kebutuhan intelektual (berprestasi). Kegiatan yang dapat dilakukan oleh guru untuk memenuhi kebutuhan penghargaan dalam pembelajaran yaitu dengan cara memberikan reward dan punishment. Pemberian reward dan punishment dalam pembelajaran memiliki implikasi yaitu siswa diakui sebagai individu unik yang memiliki kemampuan tertentu dan karakteristik yang dapat dihargai. Seorang siswa yang mendapatkan reward dari guru menandakan bahwa kemampuan yang dimiliki tentu berbeda dengan yang lain dan memiliki karakter yang positif. Sebaliknya, siswa yang mendapatkan punishment dari guru juga mengindikasikan bahwa kemampuan yang dimiliki berbeda namun ke arah yang kurang positif dan memiliki karakter yang kurang positif pula.

Walaupun secara umum reward dan punishment memiliki efek yang menyenangkan maupun tidak menyenangkan, pandangan setiap anak berbeda terhadap suatu bentuk reward dan punishment. Hal ini karena setiap anak memiliki tingkat penerimaan yang berbeda. Tingkat ini dipengaruhi oleh beberapa hal yaitu penerimaan siswa terhadap reward dan punishment, persepsi siswa terhadap pemberian reward dan punishment, dan efek psikologis pemberian reward dan punishment. Hal inilah yang harus diperhatikan dan dipikirkan oleh guru ketika menerapkan pemberian reward dan punishment. Selanjutnya, walaupun pemberian reward dan punishment memiliki beberapa hal penting yang harus diperhatikan dalam pelaksanaannya, akan tetapi hal tersebut tidak menutupi efek pemberian yang bersifat umum. Pemberian reward akan menghasilkan perasaan senang pada diri siswa sehingga siswa menjadi lebih bersemangat untuk belajar. Pemberian punishment akan menghasilkan pengalaman yang tidak menyenangkan pada siswa. Hal itu terkait dengan perilaku siswa yang kurang sesuai dengan kegiatan pembelajaran sehingga perilaku negatif tersebut dapat diminimalisir kemunculannya. Salah satu hukum belajar menurut Thorndike yaitu hukum pengaruh (the Law of Effect) dalam Hamalik berbunyi "Hubungan-hubungan diperkuat atau diperlemah tergantung pada kepuasan atau ketidaksenangan yang berkenaan dengan penggunaannya" memiliki arti bahwa kegiatan belajar seorang siswa dipengaruhi oleh kepuasan atau ketidaksenangan siswa (Hamalik, 2011).

Berdasarkan observasi peneliti di Sekolah Dasar Negeri (SDN) Dadaprejo 01 Kecamatan Junrejo Kota Batu, masih rendahnya motivasi yang diberikan oleh guru kepada siswanya dalam proses pembelajaran, sehingga peneliti melihat pada pembelajaran guru menerapkan pemberian reward dan punishment kepada siswa sebagai solusi terhadap motivasi belajar siswa. Siswa di SDN 01 Dadaprejo Kecamatan Junrejo Kota Batu, memiliki motivasi yang kurang terhadap pelajaran yang sedang berlangsung, hal ini juga disampaikan oleh wali kelas V di SDN tersebut yang menyatakan bahwa motivasi siswa terhadap pelajaran masih kurang, salah satu contohnya adalah ketika guru sedang memberikan pelajaran kepada siswa masih banyak siswa yang bermain didalam kelas pada saat kegiatan belajar mengajar 
berlangsung, siswa biasanya mulai tertib apabila guru telah menegur siswa, tetapi keadaan seperti itu tidak berlangsung lama karena siswa kembali bermain didalam kelas selama proses pembelajaran berlangsung. Selanjutnya terdapat berbagai macam permasalahan diantaranya yaitu, siswa tidak suka mengerjakan tugas yang diberikan oleh guru di sekolah, siswa kurang bersemangat dalam menerima pelajaran di sekolah, siswa jarang bertanya kepada guru terkait materi yang sedang di ajarkan oleh guru selama jam pelajaran, siswa jarang memperhatikan penjelasan guru tentang materi yang sedang dipelajarin, dan siswa juga sering terlambat masuk ke kelas.

\section{KAJIAN TEORI}

Motivasi berasal dari kata motif yang dapat diartikan sebagai kekuatan yang dapat diartikan sebagai kekukatan yang terdapat dalam diri individu, yang menyebabkan individu tersebut bertindak(Uno., 2012). Dalam Kamus Besar Bahasa Indonesia (KBBI), motivasi berarti dorongan yang timbul pada diri seseorang secara sadar dan tidak sadar untuk melakukan suatu tindakan dengan tujuan tertentu(Nasional, 2012). Motivasi adalah perubahan energi dalam diri (pribadi) seseorang yang ditandai dengan timbulnya perasaan (feeling) dan didahului dengan tanggapan terhadap adanya tujuan. Pengertian yang dikemukakan oleh Mc. Donald ini mengandung tiga elemen atau ciri pokok dalam motivasi itu, yakni motivasi itu mengawalinya terjadi perubahan energi, ditandai dengan adanya feeling dan rangsangan karena adanya tujuan"(Yamin, 2013). Motivasi adalah kekuatan penggerak yang membangkitkan aktivitas pada makhluk hidup dan menimbulkan tingkah laku, serta mengarahkannya menuju tujuan tertentu (tujuan akhir)(Zahroh, 2015). Beberapa kutipan diatas menggambarkan bahwa motivasi adalah suatu dorongan ataupun kekuatan penggerak yang ada di dalam diri seseorang baik itu muncul dari dirinya sendiri ataupun dari lingkungan luar yang dapat menimbulkan semangat dankekuatan untuk melakukan sesuatu guna tercapainya tujuan yang diharapkan, motivasi ini bertujuan untuk membangkitkan kemauan seseorang agar tergerak untuk melakukan sesuatu.

Dalam Kamus Besar Bahasa Indonesia, belajar didefinisikan sebagai: (1) berusaha memperoleh kepandaian atau ilmu, (2) berlatih, dan (3) berubah tingkah laku atau tanggapan yang disebabkan oleh pengalaman(Nasional, 2012). Belajar adalah suatu tahapan perubahan tingkah laku individu yang dinamis sebagai hasil pengalaman dan interaksi dengan lingkungan yang melibatkan unsur kognitif, efektif, dan psikomotorik(Jaya, 2015). Belajar adalah salah satu kegiatan atau usaha manusia yang sangat penting dan harus dilakukan sepanjang hayat, karena melalui usaha belajarlah kita dapat mengadakan perubahan dalam berbagai hal yang menyangkut kepentingan diri kita(Mardianto, 2016). Belajar adalah perilaku responsitif yang kuat terhadap informasi baru sepanjang kehidupan manusia(Basri., 2015). Demikianlah beberapa definisi tentang belajar yang telah dikemukakan oleh para ahli pendidikan. Kalau kita memperhatikan beberapa definisi belajar di atas, maka kita dapat menarik kesimpulan bahwa belajar ialah suatu proses usaha yang dilakukan seseorang untuk memperoleh suatu perubahan tingkah laku yang baru secara keseluruhan, sebagai hasil pengalamannya sendiri dalam interaksi dengan lingkungannya.

Kegiatan belajar, motivasi dapat dikatakan sebagai keseluruhan daya penggerak di dalam diri siswa yang menimbulkan kegiatan belajar yang menjamin kelangsungan dari kegiatan belajar, sehingga tujuan yang dikehendaki oleh subjek belajar itu dapat tercapai. Perspektif behavioral dalam psikolongi menekankan imbalan dan punishment eksternal sebagai kunci dalam menentukan motivasi murid. Intensif (stimulasi positif atau negatif yang dapat memotivasi). Intensif dapat menambah minat atau kesenangan dalam pelajaran, dan mengarahkan 
perhatian pada prilaku yang tepat dan menjauhkan mereka dari prilaku yang tidak tepat (Santrock, 2013).

Indikator motivasi belajar dapat diklasifikasikan sebagai berikut (Uno, 2012):

a. Adanya hasrat dan keinginan berhasil

b. Adanya dorongan dan kebutuhan dalam belajar

c. Adanya harapan dan cita-cita masa depan

d. Adanya penghargaan dalam belajar

e. Adanya kegiatan yang menarik dalam belajar

f. Adanya lingkungan belajar yang kondusif, sehingga memungkinkan seseorang siswa dapat belajar dengan baik.

Dari pengertian di atas maka penulis dapat menyimpulkan bahwa motivasi belajar adalah suatu dorongan untuk melakukan sesuatu guna tercapainya tujuan yang diharapkan. Jadi dalam hal ini, motivasi berperan untuk membangkitkan kemauan siswa untuk belajar. Jika dihubungkan dengan motivasi di dalam pembelajaran, siswa yang dikatakan memiliki motivasi yang tinggi dalam belajar misalnya pada mata pelajaran Matematika, maka dapat ditandai dengan memperhatikan guru saat menjelaskan pelajaran, selalu mengerjakan tugas, mampu menjawab persoalan yang ditanyakan oleh guru, dan yang lainnya.

1. Jenis-jenis Motivasi Belajar

Menurut Ivor K. Davis dalam buku karangan Sardiman ada dua jenis motivasi dalam belajar yaitu motivasi intrinsik dan motivasi ekstrinsik di bawah ini akan lebih dijelaskan secara rinci;

a. Motivasi ekstrinsik

Motivasi ekstrinsik adalah motif-motif yang aktif karena adanya perangsang dari luar. Contohnya seseorang itu belajar, karena besok pagi ada ujian dengan harapan mendapat nilai yang baik, sehingga akan dipuji oleh teman dan gurunya. Jadi, dapat dipahami bahwa motivasi ekstrinsik adalah motivasi yang berasal dari luar diri seseorang, dimana seseorang atau anak didik akan belajar dan akan melakukan suatu hal jika adanya penghargaan atas apa yang telah ia lakukan, sehingga ia tergerak untuk berusaha ataupun termotivasi untuk melakukan hal tersebut.

b. Motivasi intrinsik

Motivasi intrinsik adalah motif-motif yang menjadi aktif dan tidak perlu dirangsang dari luar, karena dalam diri setiap individu sudah ada dorongan untuk melakukan sesuatu. Contohnya seseorang yang senang membaca, tanpa ada yang menyuruhnya, ia sudah rajin mencari buku-buku untuk dibacanya. Jadi dapat dipahami bahwa motivasi intrinsik adalah motivasi yang timbul dari dalam diri seseorang atau siswa untuk terus giat dalam belajar, yang dilandasi dengan adanya tujuan yang ingin dicapainya, akan tetapi motivasi intrinsik ini juga butuh dorongan dari orang tua dan guru sehingga anak terus meningkatkan motivasinya dalam belajar.

Kata reward dalam bahasa Indonesia berarti reward. Dalam Kamus Besar Bahasa Indonesia disebutkan bahwa reward adalah hadiah (sebagai pembalas jasa)(Nasional, 2012). Secara etimologi, kata reward berasal dari kata ganjar yang berarti memberi hadiah atau upah. Dari definisi ini dapat dipahami bahwa reward dalam Bahasa Indonesia bisa dipakai untuk balasan yang baik maupun balasan yang buruk. Dalam Bahasa Arab, reward (reward) diistilahkan dengan tSawâb selalu diterjemahkan kepada balasan yang baik(Salminawati, 2015). Reward sebagai alat pendidikan diberikan ketika seorang anak melakukan sesuatu yang baik, telah berhasil mencapai suatu tahap perkembangan tertentu, atau tercapainya sebuah target(Shoimin, 2014b). Reward merupakan suatu cara untuk menggerakkan atau membangkitkan motivasi belajar siswa(Hamalik., 2013). "Dalam perspektif pendidikan, reward pada hakikatnya adalah perlakuan menyenangkan yang diterima oleh peserta didik dari pendidiknya atau guru sebagai sebuah dari prestasi dan perbuatan baik yang telah dicapai atau dilakukan oleh peserta didik.Tujuan pokoknya adalah memberikan penguatan dan motivasi agar seseorang atau anak didik lebih giat lagi dalam 
belajar dan dapat merupah perilakunya lebih baik lagi"(Siddik, 2011). Reward adalah salah satu alat pendidikan, dengan sendirinya reward itu adalah sebagai alat untuk mendidik anakanak supaya anak dapat merasa senang karena perbuatan atau pekerjaannya mendapat penghargaan (Purwanto, 2011). Tujuan utama pemberian reward tidak lain adalah agar anak merasa dihargai atas prestasinya sehingga anak akan cenderung melakukan yang terbaik dalam setiap pembelajaran(Rohmah Istikomah, Muhammad Aman Ma'mun, 2019). Dari beberapa pengertian di atas, dapat diambil satu kesimpulan bahwa pemberian reward merupakan salah satu bentuk alat pendidikan dalam proses pembelajaran yang dilakukan guru untuk anak didik sebagai satu pendorong, penyemangat dan motivasi agar anak didik lebih tergerak atau termotivasi untuk belajar dan diharapkan dari pemberian reward tersebut muncul keinginan dari diri anak untuk lebih bersemangat dalam proses pembelajaran yang tumbuh dari dalam diri anak didik tersebut.

a. Bentuk-bentuk Reward

Reward yang dapat diberikan guru bermacam-macam jenis dan bentuknya. Ada reward dalam bentuk material dan ada pula reward dalam bentuk perbuatan. Beberapa macam sikap dan perilaku guru sebagai contoh pemberian reward(M. N. Purwanto, 2016):

1) Pujian yang Mendidik

Pujian adalah suatu bentuk reward yang paling sering dilakukan. Seorang guru yang baik hendaknya memberikan pujian kepada siswa ketika ia melihat tanda-tanda yang baik dan terpuji pada diri dan prilaku siswanya. Saat ada siswa yang memberikan jawaban dari pertanyaan yang diberikan guru, ia harus mengatakan "jawaban yang kamu berikan baik sekali. Kalimat seperti akan memberika pengaruh yang baik sekali dalam jiwanya dan dapat menyebabkan ia menyukai guru dan sekolahnya.

2) Hadiah

Yang dimaksud dengan hadiah disini ialah reward yang berbentuk pemberian yang berupa barang. Reward yang berupa pemberian ini disebut juga reward materil, yaitu hadiah yang berupa barang ini dapat terdiri dari alatalat keperluan sekolah seperti pensil, penggaris, buku, dan lain sebagainya.

3) Mendo'akan

Seorang guru hendaknya memberi motivasi dengan mendoakan siswanya agar rajin belajar, sopan, dan rajin mengerjakan kewajiban agama. Guru bisa mendoakan misalnya "semoga Allah memberikan taufik untukmu", "saya harap masa depanmu cemerlang". Papan prestasi yang ditempatkan di lokasi strategis pada lingkungan sekolah merupakan sarana yang sangat bermanfaat untuk mencatat nama-nama siswa berprestasi, berprilaku baik, rajin dan menjaga kebersihan(Hartono, 2017). Dalam konteks Pendidikan Islam, bentuk reward atau reward dibedakan menjadi dua, yaitu:

1) Bentuk fisik

Yaitu perlakuan menyenangkan yang diterima seseorang dalam bentuk fisik atau material sebagai konsekuensi logis atau prestasi terbaik yang berhasil ditampilkan atau diraihnya. Misalnya, pemberian hadiah, atau pemberian penghargaan baik berupa piala, buku, beasiswa, dan lain sebagainya(Salminawati, 2015).

2) Bentuk non-fisik

Yaitu perlakuan menyenangkan yang diterima seseorang dalam bentuk non-fisik sebagai konsekuensi logis dari perbuatan baik atau prestasi terbaik yang berhasil ditampilkan atau diraihnya. Misalnya dengan cara memberikan pujian. Pujian adalah alat motivasi yang positif(Salminawati, 2015). Setiap orang senang dengan pujian, termasuk anak-anak senang dipuji atas suatu pekerjaan yang telah selesai dikerjakannya dengan baik. Kata-kata seperti kerjamu bagus, kerjamu sempurna, hebat, kamu sangat berani, good, excellent, dan sebagainya adalah sejumlah kata-kata yang biasa digunakan orang lain untuk memuji orang-orang tertentu yang dianggap berprestasi(Zahroh, 2015).

Dalam Kamus Besar Bahasa Indonesia punishment berarti siksa dan sebagainya, yang 
dikenakan kepada orang yang melanggar undang-undang dan sebagainya(Nasional, 2012). Dari sisi ini, bisa dikatakan bahwa punishment pada dasarnya merupakan perlakuan yang tidak menyenangkan yang ditimpakan pada seseorang sebagai konsekuensi atas perbuatan tidak baik yang telah dilakukan. Punishment adalah salah satu bentuk reinforcement negatif yang menjadi alat motivasi jika diberikan secara tepat dan bijak sesuai dengan prinsip-prinsip pemberian punishment"'Sardiman, 2011). Punishment adalah prosedur yang dilakukan untuk memperbaiki tingkah laku yang tak diinginkan dalam waktu singkat dan dilakukan dengan bijaksana"(Widodo, 2004). Punishment adalah konsekuensi yang menghasilkan berkurangnya tingkah laku. Punishment adalah suatu konsekuensi yang menurunkan frekuensi respon yang mengikutinya(Shoimin, 2014b). Punishment ialah konsekuensi yang tidak memberi penguatan tetapi melemahkan tingkah laku.

Para ahli didik Muslim, pada umumnya sepakat dalam menetapkan punishment dan reward sebagai alat pendidikan. Punishment dalam konsep Islam tidak identik dengan kekerasan, karena pemberian punishment adalah bertujuan untuk menumbuhkan kesadaran peserta didik bahwa perbuatan atau tindakan yang dilakukannya itu merupakan suatu yang salah atau keliru(Siddik, 2011). Jadi, dapat dikatakan bahwa punishment adalah suatu cara atau alat pendidikan yang diperlukan untuk memelihara manusia atau anak didik bukan untuk balas dendam atau menakut-nakuti, tetapi perbuatan yang dapat menyadarkan mereka atas kesalahan yang telah diperbuatnya untuk dapat terus memperbaiki diri dan tidak mengulangi kesalahan itu lagi, dan punishment juga dalam pendidikan adalah salah satu bentuk alat motivasi yang digunakan pendidik untuk memperbaiki tingkah laku yang tidak sesuai dengan norma-norma yang diyakini dengan jalan melemahkan perilaku, dilaksanakan sesuai dengan prinsip-prinsip pemberian punishment secara tepat dan bijaksana.

a. Bentuk-bentuk Pemberian Punishment Secara umum, punishment diklasifikasikan ke dalam dua bentuk, yaitu bentuk fisik dan non-fisik. Dalam Al- Qur'an punishment yang berbentuk fisik biasa berupa dipukul, dicambuk, dipotong tangan, dibunuh, denda, dan dipenjarakanatau diisolasi. Sedangkan punishment non fisik bisa berupa dihinakan Allah SWT hidupnya didunia, diterpa kegelisahan bathin, dosa, dan lainlain(Salminawati, 2015). Jadi dalam mengaplikasikan pemberian punishment, harus dapat di mengerti bahwa punishment adalah jalan terakhir dan harus dilakukan secara terbatas dan tidak menyakiti anak didik, yang harus diingat juga bahwa tujuan dari punishment ini adalah untuk menyadarkan peserta didik dari kesalahan-kesalahan yang ia lakukan dan tidak boleh ada asas balas dendam di dalamnya.

Penggunaan punishment memang diperboleh kan, akan tetapi hal ini masih dalam batas kewajaran dan tetap pada tujuan untuk mendidik. Punishment ini dapat diterapkan jika tingkah laku siswa sudah melebihi batas kewajaran(Chaplin, 2014). Beberapa bentuk punishment yang dapat diterapkan dalam pembelajaran, antara lain punishment presentasi, punishment penghapusan, dan time out. Punishment presentasi adalah penggunaan konsekuensi yang tidak menyenangkan atau rangsangan yang tidak disukai, seperti siswa disuruh menulis seperti "Saya tidak akan mengganggu kelas" 100 kali atau cacian atau tamparan, serta bisa juga bentakan. Punishment penghapusan adalah menghapus penguatan, contohnya yaitu siswa dihukum dengan tidak boleh beristirahat, berdiri didepan kelas, atau dihilngkan hak-haknya(Shoimin, 2014a).

b. Tujuan Pemberian Punishment

Tujuan punishment adalah untuk perbaikan tingkah laku atau sifat-sifat yang kurang baik dan terutama untuk kepentingan peserta didik di masa yang akan datang. 
Punishment yang edukatif akan menimbulkan rasa menyesal pada subjek didik, bukan menimbulkan rasa sakit hati atau dendam. Penyesalan atas diri sendiri dibarengi dengan kesadaran anak bahwa punishment ini juga terpaksa menimbulkan rasa kurang enak pada pendidik akibat perbuatannya, merupakan pertanda bahwa punishment tersebut diterima secara sewajarnya oleh peserta $\operatorname{didik}($ Hartono, 2017).

\section{METODE PENELITIAN}

Penelitian ini menggunakan jenis penelitian kuantitatif dengan pendekatan koresional. Metode pengambilan data yang dalam penelitian ini adalah kuesioner (angket) dengan instrument skala likert. Sedangkan teknik pengambilan sampel menggunakan total sampling dengan cara diambil dari seluruh jumlah populasi. Analisis data yang digunakan adalah analisis regresi berganda untuk mengetahui pengaruh pemberian reward dan punishment terhadap motivasi belajar siswa baik secara parsial maupun secara simultan.

\section{HASIL DAN PEMBAHASAN}

Pengaruh Reward $\left(\mathrm{X}_{1}\right)$ Terhadap Motivasi Belajar

Upaya untuk meningkatkan motivasi belajar siswa melalui pemberian reward merupakan salah satu bentuk penguatan poositif yang akan menimbulkan usaha yang lebih besar dan menjadikan belajar menjadi efektif karena siswa termotivasi mendapatkan reward dari guru dalam proses belajar mengajar yang sedang berlangsung. Reward yang merupakan penguatan positif merupakan salah satu faktor yang dapat mempengaruhi motivasi belajar siswa menurut Rifa'i(Achmad Rifa'i, 2011).

Berdasarkan data yang diperoleh dari hasil sebaran angket yang valid kepada seluruh siswa kelas V SDN Dadaprejo 01 Kecamatan Junrejo Kota Batu disajikan dalam bentuk tabel sebagai berikut:

Tabel 1. Data Pemberian Reward Statistics

\begin{tabular}{|l|r|}
\hline N $\quad$ Valid & 30 \\
Mean & 0 \\
Median & 84.80 \\
Mode & 84.50 \\
Std. Deviation & $83^{\mathrm{a}}$ \\
Variance & 1.919 \\
Range & 3.683 \\
Minimum & 6 \\
Maximum & 82 \\
Sum & 88 \\
\hline
\end{tabular}

a. Multiple modes exist. The smallest value is shown

Berdasarkan tabel di atas diperoleh skor rata-rata $=84.80$. Maka nilai tersebut dapat dikatakan berdistribusi normal. Berdasarkan ketentuan tabel tersebut, maka dapat dilakukan klasifikasi skor kecenderungan variabel $\mathrm{X}_{1}$ sebagai berikut: 
Tabel 2. Klasifikasi Kecenderungan Variabel $\mathbf{X}_{1}$

\begin{tabular}{cc}
\hline Kategori & Ketentuan \\
\hline Tinggi & $\geq 86.71$ \\
Sedang & $86.71 \mathrm{~s} / \mathrm{d} 82.88$ \\
Rendah & $\leq 82.88$ \\
\hline
\end{tabular}

Dari nilai deksripsi data pemberian reward diperoleh nilai rata-rata 84.80 dan tergolong dalam klasifikasi kecenderungan kategori variabel reward $\left(\mathrm{X}_{1}\right)$ dengan kategori sedang.

Selanjutnya peneliti menggunakan regresi linear berganda untuk mengetahui pengaruh pemberian reward terhadap motivasi belajar siswa, dengan dasar pengambilan keputusan jika signifikansi lebih besar dari
0.05 (Sign > 0.05) maka tidak terdapat pengaruh begitupun sebaliknya jika nilai signifikan lebih kecil dari 0.05 (sign < 0.05) maka terdapat pengaruh yang signifikan. Pada penelitian ini nilai yang didapat dengan menggunakan regresi linear berganda yang sebelumnya telah melewati uji normalitas, uji homogenitas, uji multikolinearitas didapatlah nilai signifikan sebesar 0,840 yang artinya lebih besar dari 0,05 yakni $(0,840 \geq 0,05)$.

Tabel 3. Uji Regresi Berganda (Variabel $X_{1}$ )

\begin{tabular}{|c|c|c|c|c|c|}
\hline \multirow[b]{2}{*}{ Model } & \multicolumn{2}{|c|}{$\begin{array}{c}\text { Unstandardized } \\
\text { Coefficients }\end{array}$} & \multirow{2}{*}{$\begin{array}{c}\text { Standardized } \\
\text { Coefficients } \\
\text { Beta }\end{array}$} & \multirow[b]{2}{*}{$\mathrm{T}$} & \multirow[b]{2}{*}{ Sig. } \\
\hline & B & $\begin{array}{l}\text { Std. } \\
\text { Error }\end{array}$ & & & \\
\hline $1 \quad$ (Constant) & 19.322 & 10.490 & & 1.842 & .076 \\
\hline$R E W A R D$ & .030 & .146 & .034 & .203 & .840 \\
\hline PUNISHMENT & .741 & .163 & .755 & 4.552 & .000 \\
\hline
\end{tabular}

a. Dependent Variabel Motivasi

Ini artinya tidak terdapat pengaruh

Reward $\left(\mathrm{X}_{1}\right)$ terhadap motivasi belajar siswa
(Y). Selanjutnya dari hasil analisis data yang dilakukan secara parsial (uji-t) menyatakan bahwa Ho diterima dan Ha ditolak.

Tabel 4. Uji $t$ (Variabel $X_{1}$ )

\begin{tabular}{|c|c|c|c|c|c|c|}
\hline \multirow[b]{2}{*}{ Model } & & \multicolumn{2}{|c|}{$\begin{array}{c}\text { Unstandardized } \\
\text { Coefficients }\end{array}$} & \multirow{2}{*}{$\begin{array}{c}\text { Standardized } \\
\text { Coefficients } \\
\text { Beta } \\
\end{array}$} & \multirow[b]{2}{*}{$\mathrm{t}$} & \multirow[b]{2}{*}{ Sig. } \\
\hline & & B & $\begin{array}{l}\text { Std. } \\
\text { Error }\end{array}$ & & & \\
\hline 1 & (Constant) & $\begin{array}{r}19.32 \\
2\end{array}$ & 10.490 & & 1.842 & .076 \\
\hline & $R E W A R D$ & .030 & .146 & .034 & .203 & .840 \\
\hline & $\begin{array}{l}\text { PUNISH } \\
\text { MENT }\end{array}$ & .741 & .163 & .755 & 4.552 & .000 \\
\hline
\end{tabular}

Hasil dari pengujian uji t (hipotesis I) menggunakan uji parsial diperoleh $t_{\text {hitung }}$ sebesar 0,203 sedangkan untuk nilai $t_{\text {tabel }} \mathrm{N}=$ 30 sebesar 0,306. Diperoleh hasil $t_{\text {hitung }}(0,203)$ $\leq \mathrm{t}_{\text {tabel }}(0,306)$. Hal ini munjukkan bahwa secara parsial untuk uji t (hipotesis I) "Tidak adanya pengaruh yang positif signifikan pemberian reward terhadap motivasi belajar siswa kelas V SDN Dadaprejo 01 Kecamatan Junrejo Kota Batu". Berarti dapat disimpulkan 
bahwa Ho diterima dan Ha ditolak.

Hal ini bertolak belakang dengan pendapat Edward Lee Thorndike yaitu, dalam hukum akibatnya (Law Of Effevact) bahwa faktor penting yang mempengaruhi motivasi belajar adalah reward atau pernyataan kepuasan dari suatu kejadian. Dalam teori conectionisme bahwasanya stimulus berupa reward yang tepat dapat mempengaruhi respon siswa yakni berupa motivasi belajar. Kemudian diperkuat oleh pendapatnya Sadirman yang mengatakan bahwa reward merupakan salah satu cara menumbuhkan motivasi berprestasi(Sardiman, 2011).

Temuan dalam penelitian ini mengatakan bahwa faktor-faktor lain di luar metode pemberian reward yang mempengaruhi motivasi belajar siswa. Faktor lainnya yang mempengaruhi motivasi belajar siswa diantaranya adalah kondisi fisik, social dan psikis siswa, pengetahuan terhadap hasil belajar, serta kurangnya peluang partisipasi dalam kegiatan belajar. Selain itu, faktor internal dan eksternal yang mempengaruhi belajar siswa juga menentukan berhasil tidaknya motivasi belajar seperti, kemampuan kognitif, gaya dan pendekatan belajar siswa, serta rasa ingin tahu. Sedangkan faktor eksternal misalnya, lingkungan siswa, fasilitas belajar, peran orang tua, sikap guru yang otoriter, penerapan metode reward yang kurang tepat, atau kendala keuangan, tingkat kebutuhan siswa yang berbeda (teori kebutuhan Adam Maslow).

Jadi, dari pembahasan diatas dapat ditarik kesimpulan bahwa reward tidak berpengaruh secara positif signifikan terhadap motivasi belajar siswa. Hal ini di latarbelakangi oleh faktor internal dan eksternal dalam proses belajar, sehingga reward tidak berfungsi sebagai alat motivasi dalam belajar. Berarti teori yang menyatakan reward (reward) bisa meningkatkan motivasi belajar tidak sepenuhnya benar, sebab dalam teori behavioristik tidak mampu menjelaskan situasi belajar yang kompleks, sebab banyak variabel yang berkaitan dengan berjalan dan tidak dapat diubah menjadi sekedar hubungan stimulus dan respon. Hal ini senada dengan yang diungkapkan oleh Ngalim Purwanto "proses belajar merupakan psikologis yang terjadi di dalam diri seseorang oleh karena itu sukar diketahui dengan pasti bagaimana terjadinya".
A. Pengaruh Punishment $\left(\mathrm{X}_{2}\right)$ Terhadap Motivasi Belajar
Berdasarkan data yang diperoleh dari hasil sebaran angket yang valid kepada seluruh siswa kelas V SDN Dadaprejo 01 Kecamatan Junrejo Kota Batu disajikan dalam bentuk tabel sebagai berikut:

Tabel 5. Data Pemberian Punishment

Statistics

PUNISHMENT

\begin{tabular}{|l|r|}
\hline N $\quad$ Valid & 30 \\
Mean & Missing \\
Median & 84.93 \\
Mode & 85.00 \\
Std. Deviation & 85 \\
Variance & 1.721 \\
Range & 2.961 \\
Minimum & 7 \\
Maximum & 80 \\
Sum & 87 \\
\hline
\end{tabular}

Berdasarkan tabel di atas diperoleh skor rata-rata $=84,93$. Maka nilai tersebut dapat dikatakan berdistribusi normal. Berdasarkan ketentuan tabel tersebut, maka 
dapat dilakukan

klasifikasi skor

kecenderungan variabel $\mathrm{X}_{2}$ sebagai berikut:

Tabel 6. Klasifikasi Kecenderungan Variabel $\mathrm{X}_{2}$

\begin{tabular}{cc}
\hline Kategori & Ketentuan \\
\hline Tinggi & $\geq 86,65$ \\
Sedang & $86,65 \mathrm{~s} / \mathrm{d} 83,20$ \\
Rendah & $\leq 83,20$
\end{tabular}

Dari nilai deksripsi data pemberian punishment diperoleh nilai rata-rata 84.93 dan tergolong dalam klasifikasi kecenderungan kategori variabel punishment $\left(\mathrm{X}_{2}\right)$ dengan kategori sedang.

Selanjutnya penelitian ini nilai yang didapat dengan menggunakan regresi linear berganda yang sebelumnya telah melewati uji normalitas, uji homogenitas, uji multikolinearitas di dapatlah nilai signifikan sebesar 0.000 yang artinya lebih kecil dari 0.05 yakni $(0.000<0.05)$ ini artinya terdapat pengaruh punishment $\left(\mathrm{X}_{2}\right)$ terhadap motivasi belajar siswa (Y).

Tabel 7. Uji Regresi Berganda (Variabel $\mathbf{X}_{2}$ )

\begin{tabular}{|c|c|c|c|c|c|}
\hline \multirow[b]{2}{*}{ Model } & \multicolumn{2}{|c|}{$\begin{array}{c}\text { Unstandardized } \\
\text { Coefficients }\end{array}$} & \multirow{2}{*}{$\begin{array}{c}\text { Standardized } \\
\text { Coefficients } \\
\text { Beta }\end{array}$} & \multirow[b]{2}{*}{$\mathrm{t}$} & \multirow[b]{2}{*}{ Sig. } \\
\hline & B & $\begin{array}{l}\text { Std. } \\
\text { Error }\end{array}$ & & & \\
\hline 1 (Constant) & 19.322 & 10.490 & & 1.842 & .076 \\
\hline REWARD & .030 & .146 & .034 & .203 & .840 \\
\hline PUNISHMENT & .741 & .163 & .755 & 4.552 & .000 \\
\hline
\end{tabular}

b. Dependent Variabel Motivasi
Ini artinya terdapat pengaruh menyatakan bahwa $\mathrm{Ha}$ diterima dan $\mathrm{Ho}$ ditolak.

yang dilakukan secara parsial (uji-t) Punishment $\left(\mathrm{X}_{2}\right)$ terhadap motivasi belajar siswa (Y). Selanjutnya dari hasil analisis data

Tabel 8. Uji t (Variabel $X_{2}$ )

\begin{tabular}{|c|c|c|c|c|c|c|}
\hline \multirow[b]{2}{*}{ Model } & & \multicolumn{2}{|c|}{$\begin{array}{l}\text { Unstandardized } \\
\text { Coefficients }\end{array}$} & \multirow{2}{*}{$\begin{array}{c}\text { Standardized } \\
\text { Coefficients } \\
\text { Beta }\end{array}$} & \multirow[b]{2}{*}{$\mathrm{t}$} & \multirow[b]{2}{*}{ Sig. } \\
\hline & & B & $\begin{array}{l}\text { Std. } \\
\text { Error }\end{array}$ & & & \\
\hline 1 & (Constant) & $\begin{array}{r}19.32 \\
2\end{array}$ & 10.490 & & 1.842 & .076 \\
\hline & $R E W A R D$ & .030 & .146 & .034 & .203 & .840 \\
\hline & $\begin{array}{l}\text { PUNISH } \\
\text { MENT }\end{array}$ & .741 & .163 & .755 & 4.552 & .000 \\
\hline
\end{tabular}

a. Dependent Variabel Y

Selanjutnya hasil pengujian hipotesis II dari hasil penelitian yang dilakukan secara parsial diperoleh $t_{\text {hitung }}$ sebesar 4.552 dengan nilai signifikansi 0.000 . Oleh karena $t_{\text {hitung }}$ (4.552) $\geq \mathrm{t}_{\text {tabel }}(0.306)$ dan nilai signifikansi
$(0.000) \leq \alpha(0.05)$. Maka dapat disimpulkan bahwa Ha diterima dan Ho ditolak. Artinya "Ada pengaruh yang positif signifikan pemberian punishment terhadap motivasi belajar siswa kelas V SDN Dadaprejo 01 Kecamatan Junrejo Kota Batu. Berdasarkan 
hasil di atas dapat disimpulkan bahwa secara parsial ada pengaruh positif antara variabel punishment $\left(\mathrm{X}_{2}\right)$ terhadap variabel $\mathrm{Y}$ (motivasi belajar).

Hal ini sesaui dengan teori Edwin Guthrie bahwa ia mengatakan punishment memgang peranan penting dalam proses belajar mengajar. Punishment yang diberikan pada saat yang tepat akan mampu memotivasi belajar siswa dan mengubah tingkah laku buruknya. Jadi, punishment yang tepat akan bisa memotivasi siswa untuk berprilaku baik dan memotivasi belajarnya. Dengan demikian hal ini sejalan dengan Amir Daien Indrakusuma dimana beliau berpendapat bahwa punishment merupakan alat pendidikan yang tidak menyenangkan, alat pendidikan yang bersifat negative, namun meski demikian dapat juga menjadi alat motivasi untuk mempergiat belajarnya siswa.

Adapaun menurut Rifa ${ }^{e c}$, Punishment yang merupakan salah satu bentuk penguatan negatif merupakan salah satu faktor yang dapat mempengaruhi motivasi belajar siswa. Punishment akan memperlemah dan menekan perilaku yang tidak diinginkan dalam pembelajaran sehingga akan menimbulkan usaha yang lebih besar dan menjadikan belajar menjadi efektif karena siswa termotivasi untuk meningkatkan motivasinya dalam belajar(Achmad Rifa'i, 2011).

Dengan adanya punishment ini diharapkan siswa bisa merubah kebiasaan buruknya seperti malas dan tidak disiplin sehingga dengan adanya punishment ini siswa termotivasi belajarnya serta bisa merubah prilaku buruknya tersebut. Sejalan dengan yang dikemukakan oleh Ngalim Purwanto punishment adalah suatu usaha guru unutk memperbaiki prilaku dan budi pekerti siswa. Dari hasil penelitian dan pendapat beberapa tokoh diatas, maka menunjukkan adanya kesesuaian antara teori dan hasil penelitian. Dimana pemberian punishment dapat meningkatkan motivasi belajar siswa dalam belajarnya. Berarti anggapan masyarakat serta para guru bahwasanya punishment adalah sesuatu hal yang buruk dan berdampak negativ tidaklah benar. Sebab, punishment yang dimaksud disini ialah yang bersifat mendidik (education) yang dapat mengubah prilaku buruk siswa dan memotivasi belajarnya bukan praktik hukumna dan siksaan yang memasung kreativitas. Berarti, hal ini sejalan dengan hasil temuan penelitian dan teori para ahli bahwasannya pemberian punishment berpengaruh secara positif signifikan terhadap motivasi belajar siswa.

Jadi, penjelasan diatas dapat disimpulkan bahwa pemberian punishment ini dalam rangka berfungsi untuk menjadikan siswa jera sehingga siswa tidak akan melakukan kesalahan-kesalahan yang serupa lagi, serta mengarahkan perubahan prilaku kearah yang lebih baik lagi dan menjadikan siswa agar lebih giat untuk belajar.

\section{SIMPULAN DAN REKOMENDASI}

Motivasi berasal dari dalam diri siswa yang tumbuh karena adanya semangat untuk meraih prestasi yang tinggi, hal itu juga disebabkan oleh kesadaran yang timbul dari diri siswa. Sedangkan untuk motivasi belajar yang berasal dari luar diri siswa biasanya muncul karena adanya rangsangan-rangsangan belajar yang berasal dari luar sehingga siswa terpacu untuk menanggapi rangsangan tersebut dengan cara menjadi lebih rajin dan lebih giat lagi untuk belajar. Pemberian reward dan punishment dalam pembelajaran memiliki implikasi yaitu siswa diakui sebagai individu unik yang memiliki kemampuan tertentu dan karakteristik yang dapat dihargai. Seorang siswa yang mendapatkan reward dari guru menandakan bahwa kemampuan yang dimiliki tentu berbeda dengan yang lain dan memiliki karakter yang positif. Pada SDN Dadaprejo kelas V Tidak terdapat pengaruh antara pemberian reward dengan motivasi belajar siswa kelas V SDN Dadaprejo 01 Kecamatan Junrejo Kota Batu dengan memperoleh thitung $(0,203) \leq$ ttabel $(0,306)$ dan nilai signifikansi $(0,840) \geq \alpha(0,05)$. Artinya, Ho diterima dan Ha ditolak. Berarti dapat disimpulkan bahwa 
secara parsial tidak adanya pengaruh positif signifikan terdapat pada variabel reward (X1) terhadap Variabel Y (motivasi belajar siswa). siswa yang mendapatkan punishment dari guru juga mengindikasikan bahwa kemampuan yang dimiliki berbeda namun ke arah yang kurang positif dan memiliki karakter yang kurang positif pula. Pada SDN Dadaprejo kelas $\mathrm{V}$ Terdapat hubungan atau pegaruh yang signifikan antara pemberian punishment terhadap motivasi belajar siswa kelas $\mathrm{V}$ di SDN Dadaprejo 01 Kecamatan Junrejo Kota Batu dengan thitung $(4,552) \geq$ ttabel $(0,306)$ dan nilai signifikansi $(0,000) \leq \alpha(0,05)$. Artinya Ha diterima dan Ho ditolak, Berarti dapat disimpulkan bahwa secara parsial ada pengaruh positif signifikan variabel punishment (X2) terhadap variabel Y (motivasi belajar).

\section{Rekomendasi}

Hasil penelitian ini diharapkan dapat menambah Kekurangan dalam penelitian ini mengenai pengaruh terhadap motivasi belajar siswa. Hasil penelitian ini dengan nilai pengaruh sebanyak $60.6 \%$ variasi motivasi belajar dapat dijelaskan oleh reward dan punishment. Sisanya Sebanyak 39.4\% dijelaskan oleh variabel lain yang tidak digunakan dalam penelitian. Pengaruh $39.4 \%$ dipengaruhi dengan model pembelajaran, strategi pembelajaran, media pembelajaran, alat peraga, pengaruh lingkungan (sekolah, orang tua, masyarakat dan alam), aktivitas belajar, dan sikap anak (efikasi diri, kemandirian, dll).

\section{DAFTAR PUSTAKA}

Achmad, R. (2011). Psikologi Pendidikan. Semarang: UNNES Press.

Basri, H. (2015). Paradigma Baru Sistem Pembelajaran. Jakarta: Pustaka Setia.

Chaplin, J. P. (2014). Kamus Lengkap Psikologi. Jakarta: Rajawali Pers.

Ginanjar, A. (2013). Metode Pembeajaran Reward. Jakarta: Rajawali Pers.

Hamalik, O. (2013). Proses Belajar Mengajar.
Bandung: Bumi Aksara.

Hamalik, O. (2011). Kurikulum dan Pembelajaran. Bandung: Bumi Aksara.

Hartono, A. (2017). Pengaruh Pemberian Reward Dan Punishment Terhadap Motivasi Belajar Peserta Didik Kelas $V$ MI AS Adiyah Banua Baru Kecamatan Wonomulyo Kabupaten Polewali Mandar. UIN Alauddin Makassar.

Jaya, F. (2015). Perencanaan Pembelajaran. Jakarta: Gema Ihsani.

Mardianto. (2016). Psikologi Pendidikan. Jakarta: Perdana Mulya Sarana.

Nasional, D. P. (2012). Kamus Besar Bahasa Indonesia (KBBI). Jakarta: Gramedia Pustaka.

Purwanto, M. N. (2016). Ilmu Pendidikan Teoritis dan Praktis. Bandung: Remaja Rosdakarya.

Purwanto, N. (2011). Ilmu Pendidikan Teoritis dan Praktis. Bandung: Rosdakarya.

Rohmah, I., Muhammad, A., \& Ma'mun, A. M. (2019). Pahala dan Hukuman dalam Pendidikan Islam. Jurnal Pendidikan Islam, 4 (3), 20-30.

Salminawati. (2015). Filsafat Pendidikan Islam. Yogyakarta: Citapustaka Media Perintis.

Santrock, J. W. (2013). Psikologi Pendidikan. Jakarta: Pustaka Media Group.

Sardiman. (2011). Interaksi dan Motivasi Belajar-Mengajar. Bandung: Rajawali Pers.

Shoimin, A. (2014a). 68 Model Pembelajaran Inovatif dalam kurikulum 2013. Jakarta: Ar-Ruzz Media.

Shoimin, A. (2014b). Model Pembelajaran Inovatif dalam kurikulum. Jakarta: ArRuzz Media.

Siddik, D. (2011). Ilmu Pendidikan Islam. Jakarta: Citapustaka Media Perintis.

Uno., H. B. (2012). Teori Motivasi dan Pengukurannya. Bandung: Bumi Aksara.

Wahyudin, A. R. (2011). Teori Belajar dan 


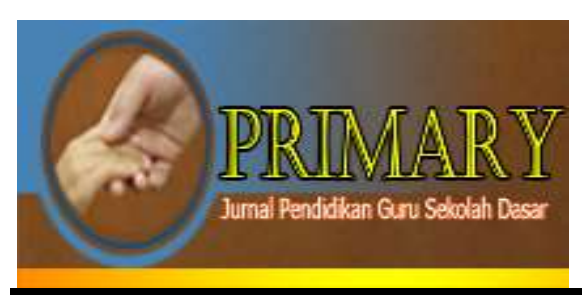

PRIMARY: JURNAL PENDIDIKAN GURU SEKOLAH DASAR

VOLUME 10 NOMOR 5 OKTOBER 2021

ISSN : 2303-1514 | E-ISSN : 2598-5949

DOI : http://dx.doi.org/10.33578/jpfkip.v10i5.8418 https://primary.ejournal.unri.ac.id/index.php/JPFKIP
Pembelajaran. Bandung: Perdana Publishing.

Widodo, A., Ahmadi., dan Supriyono. (2004). psikologi belajar. Jakarta: Perdana Publishing.
Yamin, M. (2013). Paradigma Baru Pembelajaran. Jakarta: Referensi.

Zahroh, A. (2015). Membangun Kualitas Pembelajaran melalui Dimensi Profesionalisme Guru. Jakarta: Yrama Widya. 